\title{
Keadilan Berpoligami: Tinjauan Kritis Penafsiran M. Quraish Shihab terhadap QS. Al-Nisā/4: 3
}

\author{
Nawir HK \\ UIN Alauddin Makassar \\ pasukanbersarung4772@gmail.com \\ Aan Parhani \\ UIN Alauddin Makassar \\ aan.parhani@uin-alauddin.ac.id \\ Muhammad Alwi HS \\ UIN Sunan Kalijaga Yogyakarta \\ muhalwihs2@gmail.com \\ Fahrudin \\ UIN Sunan Kalijaga Yogyakarta \\ rudinfah17@gmail.com
}

\begin{abstract}
The practice of polygamy is not a purely Islamic discourse, it existed long before the Prophet introduced the teachings of Islam. The concept of Islamic teachings tries to normalize it by being oriented towards emancipation in order to fulfil the rights of men and women in marital relations. Thus, this article aims to explore the thoughts of Quraish Shihab about his interpretation of Qur'an Al-Nisa/4: 3, where the polygamy commandment is often used as the lawfulness of that verse. There is, however, no research that reveals explicitly the fair term articulation mentioned in the verse's editorial, particularly in the context of the thinking of Quraish Shihab that is considered unique in this study. About the critical analysis paradigm based on the thinking of the characters, this research used a descriptive qualitative design. This study traces Quraish Shihab's thoughts on his ideas about the notion of polygamy through his works using library data sources. The research findings show that polygamy is only a solution for Quraish Shihab to meet the needs of an emergency household relationship as a solution, not as an excuse for fulfilling sexual desires alone. It can be seen in the emphasis of fair articulation on material fields that a person must fulfil when he wants to do polygamy. Quraish Shihab's views are categorized as moderate because he takes no part in groups of activists and opponents of polygamy, who are based on textual or contextual understanding only but try to combine the two in a single analysis to reveal the meaning of the concept of polygamy on Al-Nisā: 3 .
\end{abstract}

Keywords: Quraish Shihab; QS. Al-Nisa/4: 3; Fair; Polygamy.

\begin{abstract}
Abstrak
Praktik poligami bukanlah wacana yang murni bersumber dari ajaran Islam, eksistensinya telah hadir jauh sebelum ajaran Islam dibawa oleh Rasulullah. Konsep ajaran Islam justru berusaha untuk menormalisasinya dengan berorientasi pada emansipasi untuk pemenuhan hak-hak hubungan pernikahan bagi laki-laki dan perempuan. Dengan demikian, maka artikel ini bertujuan untuk menggali pemikiran M. Quraish Shihab terkait penafsirannya tentang QS. AlNisa/4: 3, ayat yang kerap kali digunakan sebagai legalitas perintah poligami. Namun demikian, belum ada penelitian yang secara spesifik mengungkap artikulasi term adil yang disebutkan di dalam redaksi ayat tersebut, khususnya dalam konteks pemikiran M. Quraish Shihab yang dinilai unik dalam kajian ini. Penelitian ini menggunakan desain kualitatif deskriptif dengan mengacu pada paradigma analisis kritis berbasis pemikiran tokoh. Dengan menggunakan sumber data pustaka, kajian ini menelusuri pemikiran M. Quraish Shihab terhadap
\end{abstract}


pemikirannya tentang konsep poligami melalui karya-karyanya. Hasil telitian menunjukkan bahwa bagi M. Quraish Shihab poligami hanyalah sebagai solusi dalam memenuhi kebutuhan hubungan rumah tangga yang bersifat darurat sebagai solusi, bukan sebagai dalih untuk memenuhi keinginan hasrat seksual semata. Hal itu tampak pada penekanan artikulasi term adil pada wilayah material yang harus dipenuhi oleh seorang laki-laki ketika hendak berpoligami. Pandangan M. Quraish Shihab itu tergolong moderat karena tidak berpihak pada kelompok penggiat dan penentang praktik poligami yang hanya berlandaskan pada pemahaman tekstual atau kontekstual semata, melainkan berusaha memadukan keduanya sebagai satu kesatuan analisis untuk mengungkap pesan signifikansi konsep poligami yang terkandung di dalam QS. Al-Nisa/4:3.

\section{Kata Kunci: M. Quraish Shihab; QS. Al-Nisa/4:3; Adil; Poligami.}

\section{A. Pendahuluan}

Poligami merupakan salah satu isu dari sekian fenomena keberagamaan yang terus hangat diperbincangkan oleh berbagai kalangan agamawan. Sebagian dari mereka mengklaim bahwa poligami merupakan perintah syariat dalam ajaran Islam yang bersifat mutlak, namun sebagian di antaranya memosisikan poligami sebagai tradisi klasik yang berusaha di normalisasi melalui syarat-syarat yang ketat yang ditetapkan di dalam ajaran Islam. Salah satu syarat yang paling ditekankan oleh para ulama adalah pemenuhan syarat adil bagi pelaku poligami secara mutlak. Dalam diskursus penafsiran teks-teks keagamaan (al-Qur'an), sikap adil masih menjadi bias penafsiran, sebagian mufasir memahami term adil pada tataran kemampuan material, sedangkan sebagian lainnya memahami adil pada tataran kemampuan mental. Menanggapi persoalan itu, M. Quraish Shihab tampak berbeda dalam meletakkan term adil itu berdasarkan penafsirannya terhadap QS. Al-Nisa/4:3. Menurutnya bahwa ayat itu bukan sebagai syarat dalam melegalkan praktik poligami, karena pada kenyataannya hal itu telah dipraktikkan dan dikenal dalam tradisi masyarakat Arab klasik sebelum turunnya al-Qur'an. Akan tetapi ayat itu hanya menekankan legalitas poligami keadaan atau kondisi tertentu yang bersifat darūrī.

Pandangan M. Quraish Shihab tersebut mengundang banyak perhatian dari kalangan peneliti. Namun demikian, kajian-kajian itu masih terbatas pada konsep poligami secara umum, baik yang bersifat kajian pemikiran tunggal maupun kajian komparasi pemikiran dengan tokoh lainnya. Penelitian yang mengkaji pemikiran M. Quraish Shihab secara tunggal diataranya telah dilakukan oleh Achmad Dhafir (2018), ${ }^{2}$ Ali Bahron (2015), ${ }^{3}$ Hijrah (2017), ${ }^{4}$ Siti Asiyah, Muhammad Irsad, Eka Prasetiawati dan Ikhwanuddin (2019), ${ }^{5}$ Ahmad Khotim (2019), ${ }^{6}$ dan Rusli Halil Nasution (2018). ${ }^{7}$ Sementara yang melakukan komparasi sebagaimana yang

\footnotetext{
${ }^{1}$ M. Quraish Shihab, Wawasan Al-Qur'an, Tafsir Tematik atas Pelbagai Persoalan Umat (Bandung: Mizan, 1996), 264-265.

${ }^{2}$ Achmad Dhafir, “Asas-asas Berpoligami dalam al Qur'an: Studi dalam Tafsir al-Misbah karya M. Quraish Shihab” (Tesis, Surabaya: UIN Sunan Ampel, 2018).

${ }^{3}$ Ali Bahron, "Pemikiran M. Quraish Shihab tentang Adil dalam Poligami" (Skripsi, Jember: IAIN Jember, 2015).

${ }^{4}$ Hijrah Hijrah, "Pemikiran Quraish Shihab tentang Poligami dan Relevansinya terhadap Kompilasi Hukum Islam dan UU No. 1 Tahun 1974 Tentang Perkawinan di Indonesia: Studi atas Karya-karya Quraish Shihab” (Tesis, Mataram: Universitas Islam Negeri Mataram, 2017).

${ }^{5}$ Siti Asiyah dkk., "Konsep Poligami dalam Alquran: Studi Tafsir Al-Misbah Karya M. Quraish Shihab," Fikri: Jurnal Kajian Agama, Sosial dan Budaya 4, no. 1 (2019): 85-100, https://doi.org/10.25217/jf.v4i1.443.

${ }^{6}$ Ahmad Khotim dan Gempur Malessantoro, "Adil Dalam Poligami Menurut Kyai Di Jombang Perspektif M. Quraish Shihab,” At-Tahdzib: Jurnal Studi Islam dan Muamalah 7, no. 2 (2019): 80-99.

${ }^{7}$ Rusli Halil Nasution, “Adil menurut Quraish Shihab dalam Al-Qur'an terhadap Praktek Poligami," Jurnal Hukum Responsif 6, no. 6 (2019): 21-31.
} 
dilakukan oleh Moch Cholik Chamid Muttakin (2018), ${ }^{8}$ dan Ali Yasmanto (2015). ${ }^{9}$ Akan tetapi, kajian itu tidak menempatkan pemikiran M. Quraish Shihab sebagai satu dari sekian banyak pemikiran tentang penafsiran term adil sebagai bagian dari diskursus penafsiran ayat-ayat poligami, khususnya dalam QS. Al-Nisa/4: 3. Padahal, M. Quraish Shihab menilai term adil penting untuk dipahami dalam ayat itu agar tidak menimbulkan bias penafsiran tentang ayatayat poligami dalam al-Qur'an. Oleh karena itu, kajian ini lebih difokuskan pada aspek itu, demi melengkapi kajian-kajian sebelumnya dengan mengacu pada pertanyaan, mengapa $\mathrm{M}$. Quraish Shihab menganggap penting untuk memahami secara komprehensif hubungan antara term adil dengan konsep poligami dalam QS. Al-Nisa/4: 3?

Demi mendapatkan jawaban yang bersifat transformatif terhadap pertanyaan penelitian itu, maka kajian ini menggunakan desain penelitian kualitatif berbasis paradigma kritis. Hal itu dilakukan mengumpulkan hasil pemikiran M. Quraish Shihab yang dilansir dari berbagai karyakaryanya tentang hubungan antara term adil sebagai bagian dari konsep poligami dalam ajaran Islam. Selanjutnya, untuk memosisikan hasil pemikiran M. Quraish Shihab itu dalam ranah diskursus akademik, maka hasil temuan itu dibandingkan dengan berbagai pemikiran tokoh agamawan lainnya. Penelitian ini berargumen bahwa term adil tidak hanya diposisikan sebagai syarat dalam perwujudan praktik poligami, melainkan ia juga sangat erat kaitannya dengan kondisi dan keadaan darurat bagi seorang laki-laki yang hendak melakukan praktik poligami. Bagi M. Quraish Shihab poligami bukanlah keinginan yang dapat dilakukan bagi siapa saja, melainkan sebagai kebutuhan yang hanya dapat dilakukan berdasarkan keadaan darurat dan kemampuan seorang laki-laki untuk bersikap adil dalam memenuhi aspek material para istriistrinya.

\section{B. Hasil dan Pembahasan}

\section{B.1. Sejarah Intelektual M. Quraish Shihab}

M. Quraish Shihab merupakan salah seorang putera asli Sulawesi Selatan yang lahir di kota Rapang pada tanggal 16 Februari 1944 M. ${ }^{10}$ Dia menikah dengan Fatmawati Assegaf dan memiliki lima orang anak, yaitu Najeela Shihab, Najwa Shihab, Nashwa Shihab, Ahmad Shihab dan Nahla Shihab. ${ }^{11}$ Ia lahir dari keluarga yang terpelajar dan berdarah Arab. Ayahnya yang bernama Abdurrahman Shihab adalah seorang ulama yang pakar di bidang tafsir al-Qur'an dan pernah menjabat sebagai rektor pada Universitas Muslim Indonesia (UMI) dan UIN Alauddin Makassar (sebelumnya IAIN Alauddin). Dari ayahnya itulah, M. Quraish Shihab mendapatkan kecintaan dan motivasi untuk mempelajari disiplin tafsir al-Qur'an secara mendalam. ${ }^{12}$

Selain mendapatkan pendidikan dari ayahnya, M. Quraish Shihab mendapat pendidikan formal di Makassar. Kemudian ia melanjutkan pendidikannya di Pesantren Darul Hadis alFalaqiyah yang terletak di kota Malang. M. Quraish Shihab kemudian melanjutkan pendidikannya ke al-Azhar Mesir pada tahun 1958 dan diterima di kelas dua madrasah tsanawiyah (setingkat SMP). Pengembaraan keilmuannya tidak selesai sampai di situ, ia kemudian melanjutkan ke Jurusan Tafsir Hadis Fakultas Ushuluddin Universitas al-Azhar. Gelar Lc. diraihnya pada tahun 1967 dan pendidikan masternya diselesaikan pada tahun 1969 dengan menulis tesis yang berjudul I'jāz at-Tasyrī' al-Qur'ān al-Karìm. Setelah menyelesaikan

\footnotetext{
${ }^{8}$ Moch Cholik Chamid Muttakin, "Konsep Poligami Perspektif Al-Qur'an (Studi Komparasi Pemikiran ArRazi \& M Quraish Shihab)” (Skripsi, Tulungagung, Iain Tulungagung, 2018).

${ }^{9}$ Ali Yasmanto, "Konsep adil dalam poligami: Studi komparasi antara pemikiran Fazlur Rahman dan M. Quraish Shihab” (Tesis, Malang, Universitas Islam Negeri Maulana Malik Ibrahim, 2015).

${ }^{10}$ Dewan Redaksi, Suplemen Ensiklopedi Islam (Jakarta: Ichtiar Baru Van Hoeve, 1994), 110.

${ }^{11}$ M. Quraish Shihab, Mukjizat al-Qur'an ditinjau dari Aspek Kebahasaan, Isyarat Ilmiah, dan Pemberitaan Gaib (Bandung: Mizan, 2002), 8-9.

${ }^{12}$ Islah Gusmian, Khazanah Tafsir Indonesia DAri Hermeneutika hingga Ideologi (Yogyakarta: LKiS, 2013), 80 .
} 
studinya itu, dia sempat kembali ke Indonesia pada tahun 1973 untuk membantu ayahnya yang saat itu menjabat sebagai rektor di IAIN Alauddin (sekarang UIN Alauddin). M. Quraish Shihab kemudian menjabat sebagai wakil rektor bidang akademik dan kemahasiswaan sampai tahun 1980. Pada tahun 1980 tersebut, M. Quraish Shihab kembali ke Kairo untuk melanjutkan studi di Universitas al-Azhar mengambil pendidikan doktoral dalam disiplin Tafsir al-Qur'an. Hanya dalam waktu dua tahun M. Quraish Shihab menyelesaikan pendidikan doktoralnya dengan menulis disertasi yang berjudul "Nazm ad-Durar li al-Biqa'i Tahqiq wa Dirasah (Suatu Kajian terhadap Kitab Nazm ad-Durar (Rangkaian Mutiara) karya al-Biqa'i)". Kenyataan bahwa M. Quraish Shihab menempuh pendidikan tingginya di Timur Tengah dinilai oleh Howard M. Federspiel sebagai keunikan bagi Indonesia mengingat ketika itu pendidikan tinggi banyak diselesaikan di Barat. ${ }^{13}$

Setelah kembali ke Indonesia dan melanjutkan tugasnya di IAIN Alauddin, pada tahun 1984 M. Quraish Shihab dipindahtugaskan ke fakultas Ushuluddin UIN Jakarta. ${ }^{14}$ Di almamater barunya tersebut, ia aktif mengajar tafsir dan ilmu al-Qur'an di program S1, S2, dan S3 hingga tahun 1998. M. Quraish Shihab juga pernah menjabat sebagai rektor di UIN Jakarta untuk periode 1992-1996 dan 1997-1998 selain itu, M. Quraish Shihab juga pernah menjabat sebagai Menteri Agama RI selama dua bulan di awal 1998. ${ }^{15}$ Kemudian ia diangkat menjadi Duta Besar Luar Biasa dan Berkuasa Penuh Republik Indonesia untuk negara Republik Arab Mesir dan Republik Djibouti yang berkedudukan di Kairo. Sebelum menduduki jabatan diplomatik tersebut, M. Quraish Shihab tercatat pernah menjabat sebagai ketua Majelis Ulama Indonesia (MUI) Pusat sejak tahun 1984, anggota Lajnah Pentashih al-Qur'an Departemen Agama RI sejak tahun 1989. Selain itu, M. Quraish Shihab juga pernah menjabat sebagai Asisten Ketua Umum Ikatan Cendekiawan Muslim Indonesia (ICMI). ${ }^{16}$

M. Quraish Shihab merupakan ulama yang produktif dengan melahirkan banyak karya, di antaranya adalah Tafsir al-Manar; Keistimewaan dan Kelemahannya (1984), Satu Islam, Sebuah Dilema (1987), Filsafat Hukum Islam (1987), Pandangan Islam Tentang Perkawinan Usia Muda (1990), Lentera Hati (1994), Studi Kritis Tafsir Al-Manar (1996), Tafsir Al-Qur'an (1997), Menyingkap Tabir Ilahi (1998), Untaian Permata Buat Anakku (1998), Haji Bersama Quraish Shihab (1999), Sahur Bersama Quraish Shihab (1999), Hidangan Ilahi (1999), FatwaFatwa M. Quraish Shihab Seputar Ibadah Mahdah (1999), Jalan Menuju Keabadian (2000), Panduan Shalat bersama Quraish Shihab (2003), Menjemput Maut (2003), Tafsir Al-Misbah (2003), Wawasan Al-Qur'an (2007), Ensklopedia Al-Qur'an (2007), Secercah Cahaya Ilahi (2013), Jilbab Pakaian Wanita Muslimah (2004), Dia di Mana-mana (2004), Perempuan (2005), Logika Agama (2005), Rasionalitas Al-Qur'an (2006), Menabur Pesan Ilahi (2006), Wawasan Al-Qur'an Tentang Dzikir dan Doa (2006), Sunni-Syiah Bergandengan Tangan! Mungkinkah? (2007), Membumikan Al-Qur'an (2013), Kaedah Tafsir (2013) dan lainnya.

\section{B.2. Tuntutan Poligami: Antara Tradisi Patriarki dan Syariat Islam}

Pada dasarnya poligami bukanlah praktik yang lahir dari rahim Islam, melainkan telah eksis sebelumnya dalam sistem tradisi masyarakat Arab pra-Islam yang bersifat patriarkis. Patriarki adalah perilaku yang melebihkan peran laki-laki dari perempuan, serta memosikannya sebagai aktor utama dalam sistem menejerial kehidupan. Dalam tradisi patriarki, posisi menejerial perempuan dikuasai oleh laki-laki sebagai salah satu penunjang kebutuhannya. Perilaku patriarki ini tidak hanya dijumpai di jazirah Arab, namun juga dijumpai dalam tradisi

\footnotetext{
${ }^{13}$ Howard M. Federspiel, Tajul Arifin, dan Rachmat Taufiq Hidayat, Kajian Al-Quran Di Indonesia: Dari Mahmud Yunus Hingga Quraish Shihab (Bandung: Mizan, 1996), 295.

${ }^{14}$ M. Quraish Shihab, Menabur Pesan Ilahi; Al-Qur'an dan Dinamika Kehidupan Masyarakat (Jakarta: Lentera Hati, 2006), vi.

${ }^{15}$ M. Quraish Shihab, Secercah Cahaya Ilahi: Hidup Bersama al-Quran (Bandung: Mizan, 2013), 6.

${ }^{16}$ Gusmian, Khazanah Tafsir Indonesia, 80.
} 
peradaban kuno di berbagai kawasan lainnya di sekitar Jazirah Arab, seperti Mesopotamia dan Mediterania. ${ }^{17}$ Dengan demikian, praktik poligami pada dasarnya sudah terjadi secara luas di berbagai tradisi di negara dan bangsa sebelum datangnya Islam. Oleh karena itu, tidak dapat dibenarkan jika ada asumsi yang mengklaim bahwa poligami bersumber dari ajaran Islam semata, bahkan hingga era modern ini praktik poligami juga dianut oleh masyarakat di berbagai negara seperti China, Afrika, Jepang dan Hindu India. ${ }^{18}$

Poligami juga dikenal dalam bangsa Israel dengan tanpa ada pembatasan jumlah perempuan yang dijadikan istri. ${ }^{19}$ Kitab Samuel II pasal 12 memberikan keterangan bahwa Nabi Hatsan berkata kepada Daud, "Aku telah menundukkan sebagai raja bangsa Israel dan aku telah melepaskan engkau dari ancaman Seul dan aku telah memberikan kepadamu istana dan istri-istri tuanmu, kenapa engkau mengambil istri Quera menjadi istrimu?". Kemudian pada pasal 111 dari kitab raja-raja dijelaskan bahwa raja Sulaiman mencintai wanita-wanita dari bangsa-bangsa asing, bersama dengan putri-putri Fir'aun yang terdiri dari suku bangsa Moaby, Amon Aramy, Sayduny dan Haysy. Sulaiman berhubungan dengan mereka karena cintanya. ${ }^{20}$

Di tengah peradaban bangsa-bangsa yang mempraktikkan poligami tanpa ada batasan jumlah, Islam kemudian datang merespons kesenjangan itu dengan menawarkan kebijakan aturan dalam praktik poligami yang telah mengakar sebelumnya. Melalui ajaran Islam yang diajarkan oleh Nabi Muhammad secara tegas melarang berbagai praktik penyimpangan dalam hubungan pernikahan, termasuk poligami yang tidak dibatasi secara kuantitasnya. Islam kemudian mengatur bahwa batasan jumlah perempuan yang boleh dinikahi dalam praktik poligami hanya maksimal kepada empat orang, serta dengan disyaratkan suami yang berpoligami harus berlaku adil. Selain itu, Islam datang untuk memuliakan perempuan dengan memberikan hak-haknya dan memberi perempuan kedudukan yang tidak berbeda dengan lakilaki. $^{21}$ Praktik poligami juga dapat ditemukan di bangsa Eropa. Hal ini diungkapkan oleh Wetermeach seorang ahli sejarah yang berkebangsaan Eropa. Dia mengungkapkan bahwa raja Irlandia yang bernama Diamat memiliki empat orang istri. Demikian juga dengan raja-raja Meriving yang sering melakukan poligami. Bahkan di beberapa sekte Agama Kristen terdapat ajaran yang mewajibkan berpoligami. Seperti sekte Mormon yang meyakini poligami adalah ajaran suci dari Tuhan. ${ }^{22}$

Hussein Muhammad mengungkapkan bahwa para ulama terbagi menjadi tiga kelompok dalam perdebatan tentang eksistensi poligami di dalam ajaran Islam. Kelompok pertama secara mutlak membolehkan poligami. Kelompok ini menilai poligami adalah salah satu sunnah, yaitu mengamalkan apa yang dilakukan oleh nabi Muhammad. Akan tetapi, kelompok ini cenderung abai dengan syarat adil dalam poligami seperti yang telah disebutkan oleh al-Qur'an secara jelas. Kedua, kelompok yang secara mutlak melarang poligami. Pendapat kelompok ini berlandaskan pada kenyataan bahwa Nabi Muhammad sepanjang hayatnya lebih lama dalam jalinan pernikahan yang monogami daripada poligami. Ketiga, kelompok yang menetapkan kebolehan poligami namun harus memenuhi syarat-syarat tertentu dan harus berada dalam kondisi-kondisi tertentu. ${ }^{23}$

Sejarah praktik poligami setidaknya dapat disimpulkan dalam tiga poin, seperti yang diungkapkan oleh Mustafa as-Siba'i. Tiga poin tersebut adalah, pertama praktik poligami sudah

\footnotetext{
${ }^{17}$ Humaidi Tatapangarsa, Hakekat poligami dalam Islam (Jakarta: Usaha Nasional, 1999), 7.

${ }^{18}$ Sayyid Sabiq, Fikih Sunnah, trans. oleh al-Ma'arif (Bandung, 1987), 169.

${ }^{19}$ Tatapangarsa, Hakekat poligami dalam Islam, 15.

${ }^{20}$ Abbas Mahmud al-Aqqad, al-Mar'ah fi Al-Qur'an, trans. oleh Chadijah Nasution (Jakarta: Bulan Bintang, 1987), 133.

${ }^{21}$ Syed Ameer Ali, The Spirit of Islam, trans. oleh HB. Jasin (Jakarta: Bulan Bintang, 2000), 384.

${ }^{22} \mathrm{Al}$-Aqqad, al-Mar'ah fi Al-Qur'an, 136.

${ }^{23}$ Husein Muhammd, Noor Rachman, dan A. Dicky Sofyan, Ijtihad Kyai Husein: Upaya Membangun Keadilan Gender (Jakarta: Rahima, 2011), 17.
} 
ada sejak era sebelum Islam dan bukan agama Islam yang pertama kali mengajarkannya. Kedua, poligami tanpa batasan jumlah diperbolehkan dalam ajaran agama Yahudi. Bahkan semua Nabi yang diceritakan oleh Taurat melakukan poligami. Ketiga, agama Kristen tidak secara tegas melarang poligami, namun hanya memberikan nasehat-nasehat. Dengan demikian dapat dilihat bahwa poligami dipraktikkan secara luas dalam bangsa-bangsa dan agama-agama dunia.

\section{B.3. Penafsiran M. Quraish Shihab terhadap Term Adil dalam QS. Al-Nisa/4:3}

Sub pembahasan ini mengulas pemikiran M. Quraish Shihab terkait penafsiran QS. AlNisa/4:3 tentang term adil dalam praktik poligami. Berikut redaksi ayatnya:

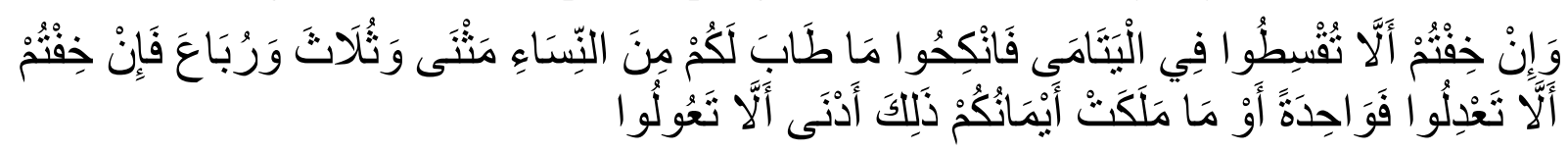

"Jika kamu khawatir tidak akan mampu berlaku adil terhadap (hak-hak) perempuan yatim (bilamana kamu menikahinya), nikahilah perempuan (lain) yang kamu senangi: dua, tiga, atau empat. Akan tetapi, jika kamu khawatir tidak akan mampu berlaku adil, (nikahilah) seorang saja atau hamba sahaya perempuan yang kamu miliki. Yang demikian itu lebih dekat untuk tidak berbuat zalim"24

Dalam konteks ini, M. Quraish Shihab menafsirkan ayat tersebut dengan melihat sisi tekstual dan kontekstual-historisnya. Dia menjelaskan bahwa melalui ayat tersebut, Allah melarang untuk berbuat aniaya terhadap anak yatim dan memakan harta anak yatim. Setelah itu, Allah melarang berlaku aniaya terhadap pribadi anak-anak yatim itu. Hal itu dapat dilihat pada kutipan pernyataan M. Quraish Shihab sebagai berikut:

"dan jika kamu takut tidak akan dapat berlaku adil terhadap perempuan yatim, dan kamu percaya diri akan berlaku adil terhadap wanita-wanita selain yatim itu, maka nikahilah apa yang kamu senangi sesuai selera kamu dan halal dari wanita-wanita yang lain itu, kalau perlu, kamu dapat menggabung dalam saat yang sama dua, tiga atau empat tetapi jangan lebih, lalu jika kamu takut tidak dapat berlaku adil dalam hal harta dan perlakuan lahiriah, bukan dalam hal cinta bila menghimpun lebih dari seorang istri, maka nikahilah seorang saja, atau nikahi hamba sahaya wanita yang kamu miliki. Yang demikian itu, yaitu menikahi selain anak yatim mengakibatkan ketidakadilan, dan mencukupkan satu orang istri adalah lebih dekat kepada tidak berbuat aniaya, yaitu lebih mengantarkan kamu kepada keadilan, atau kepada tidak memiliki banyak anak yang harus kamu tanggung biaya hidup mereka". ${ }^{25}$

Selanjutnya, M. Quraish Shihab juga menjelaskan berbagai term yang digunakan dalam QS. Al-Nisa/4:3 seperti, "tuqsitüu” dan "tu'dilü". Kedua kata ini diterjemahkan ke dalam bahasa Indonesia sebagai "adil". Walaupun demikian, ulama berbeda pandangan dalam memaknai kedua term tersebut. Sebagian ulama menilai bahwa kedua term tersebut memiliki arti yang sama, dan sebagian ulama yang lain membedakan keduanya. Mereka yang membedakannya menganggap bahwa term "tuqsiț $\vec{u}$ " adalah bersikap adil terhadap dua orang atau lebih yang membuat mereka senang. Sedangkan " $t a$ 'dilu" adalah bersikap adil terhadap dua orang atau lebih namun tidak harus membuat mereka smeua senang. Selain itu, ayat ini juga memuat pembicaraan tentang perbudakan pada redaksi "mā malakat aimanukum". Penggalan ayat ini biasanya diterjemahkan sebagai "hamba sahaya wanita yang kamu miliki". Namun demikian, pada dasarnya Islam tidak membenarkan praktik perbudakan walau ketika al-Qur'an

\footnotetext{
${ }^{24}$ Lajnah Pentashihan Mushaf Al-Qur'an Badan Litbang dan Diklat Kementerian Agama RI, Al-Qur'an Dan Terjemahnya; Edisi Penyempurnaan (Jakarta, 2019), 104.

${ }^{25}$ Quraish Shihab, Tafsir Al-Misbah Pesan, Kesan dan Keserasian al-Qur'an (Jakarta: Lentera Hati, 2011), 322.
} 
diturunkan, penghapusan sistem perbudakan itu tidak dilakukan secara langsung dan sekaligus. Al-Qur'an dan Sunnah meniadakan semua jalan yang berpotensi menyebabkan berkembangnya praktik perbudakan. Jalan yang tidak ditutup hanya tawanan yang terjadi akibat peperangan dalam rangka mempertahankan jiwa dan agama. Meskipun Islam memperkenankan menjadikan tawanan perang sebagai budak, akan tetapi perlakuannya sangat manusiawi bahkan penguasa muslim diberi wewenang untuk membebaskan tawanannya itu dengan tebusan maupun tanpa tebusan. ${ }^{26}$

Cara yang ditempuh oleh Islam dalam menghapus sistem perbudakan adalah bertahap dan berangsur-angsur. M. Quraish Shihab berpendapat bahwa penafsiran yang paling tepat terhadap ayat di atas adalah penafsiran yang didasarkan pada riwayat dari Bukhari, Muslim, Abu Daud dan al-Tirmizi bahwa Urwah bin Zubair bertanya kepada 'Āisyah tentang ayat ini. Beliau menjawab bahwa ayat ini berkenaan dengan anak yatim yang sedang berada dalam asuhan walinya, dimana hartanya menyatu dengan harta walinya dan walinya itu senang dengan kecantikan dan harta anak yatimnya. Maka walinya itu hendak menikahinya namun dengan memberi mahar yang sesuai. ${ }^{27}$

'Aisyah kemudian menjelaskan bahwa ketika ayat ini turun, para sahabat bertanya lagi kepada Nabi tentang perempuan. 'Aisyah kemudian melanjutkan keterangannya bahwa firman Allah: sedang kamu enggan menikahi mereka, bahwa itu adalah keengganan para wali untuk menikahi anak yatim yang sedikit harta dan kecantikannya. Maka sebaliknya dalam QS. AlNisa'/4:3 ini, mereka dilarang menikahi anak-anak yatim yang mereka inginkan karena harta dan kecantikannya tetapi enggan berlaku adil terhadap mereka. ${ }^{28}$ Redaksi dua, tiga atau empat pada ayat ini sebenarnya adalah untuk menjadi tuntunan agar berbuat adil kepada anak yatim. Redaksi tersebut sepadan dengan ucapan seseorang yang melarang orang lain untuk memakan suatu makanan. Untuk menguatkan larangannya itu ia berkata, "jika anda khawatir akan sakit bila makan makanan ini maka habiskan saja makanan selainnya yang ada di hadapan anda”. Perintah ini bertujuan untuk mempertegas perlunya mengindahkan larangan agar tidak makan makanan tertentu. M. Quraish Shihab menggarisbawahi bahwa maksud utama ayat ini adalah tidak membuat peraturan tentang poligami, karena poligami telah dikenal dan dilaksanakan oleh penganut berbagai syariat agama, serta adat istiadat masyarakat sebelum turunnya alQur'an. ${ }^{29}$

M. Quraish Shihab menegaskan bahwa tidak ada indikasi yang menunjukkan kewajiban perintah berpoligami dalam ayat ini, melainkan hanya memuat tentang kebolehan berpoligami dengan syarat-syarat yang tidak ringan. Ayat ini kemudian diakhiri dengan anjuran untuk monogami yang termuat dalam redaksi "yang demikian itu adalah lebih dekat kepada tidak berbuat aniaya”. M. Quraish Shihab menambahkan bahwa terdapat beberapa hal yang penting untuk digarisbawahi dari ayat ini yaitu, Pertama, sasaran ayat ini adalah para wali anak yatim yang hendak menikahi anak yatimnya dengan tanpa berbuat adil. Sehingga secara leterlijk dapat dikatakan bahwa kebolehan poligami hanya bagi para wali anak yatim, bukan semua laki-laki. Kedua, kata "khiftum", yang kadang diterjemahkan sebagai "takut" atau kadang pula diterjemahkan sebagai "mengetahui". Artinya, terjemahan kedua itu menunjukkan bahwa mereka yang tidak diperkenankan berpoligami adalah siapa saja yang yakin atau menduga tidak mampu berbuat adil terhadap istri-istrinya yang yatim maupun bukan. Ketiga, huruf waw pada ayat ini berarti atau, bukan dan. ${ }^{30}$

\author{
${ }^{26}$ Shihab, 322. \\ ${ }^{27}$ Shihab, 323. \\ ${ }^{28}$ Shihab, 324. \\ ${ }^{29}$ Shihab, 324. \\ ${ }^{30}$ M. Quraish Shihab, Perempuan (Tangerang: Lentera Hati, 2014), 181-83.
}


M. Quraish Shihab juga menekankan sisi keadilan sebagai faktor mutlak dalam berpoligami berdasarkan penafsirannya terhadap QS. Al-Nisa'/4:3. Hal ini karena baginya keadilan merupakan faktor mendasar dan bersifat mutlak yang harus terpenuhi bagi seseorang yang hendak berpoligami. Keadilan yang dimaksud ayat ini menyangkut banyak aspek karena QS. al-Nisa/4:3 berkaitan erat dengan ayat sebelumnya yang bertujuan untuk mengingatkan para wali agar mengelola harta anak yatim secara adil. ${ }^{31}$ Pemahaman tentang keadilan yang mengerucut pada konteks sikap suami kepada para istri dijawab oleh M. Quraish Shihab dengan menyatakan bahwa keadilan dalam ayat ini berkenaan dengan anak-anak yatim. Pemahaman M. Quraish Shihab yang demikian ini lahir dari penafsirannya yang melihat munasabah ayat serta melihat latar turunnya ini yang berupa realitas banyaknya janda dan anak yatim pasca perang Uhud.

Keadilan yang dimaksud oleh M. Quraish Shihab dalam poligami adalah keadilan material, bukan immateril atau mental (cinta dan kasih sayang). Hal itu didasarkannya pada penafsiran QS. al-Nisa/4:129. ${ }^{32}$ Dalam ayat tersebut tersirat bahwa keadilan secara menyeluruh atau pada tataran immateril tidak mungkin dapat dicapai oleh manusia. Itulah sebabnya, $\mathrm{M}$. Quraish Shihab berkesimpulan bahwa keadilan dalam poligami hanya pada aspek material semata. ${ }^{33}$ Meskipun keadilan mutlak mustahil untuk diwujudkan, namun bukan berarti hal itu menjadi alasan untuk membatalkan hukum kebolehan poligami. Sehingga asumsi yang menjadikan QS. al-Nisa/4:129 sebagai legitimasi untuk melarang poligami tidak dapat diterima. ${ }^{34}$ Keadilan yang tidak mungkin terwujud dalam hal ini perihal cinta atau suka berdasarkan perasaan, sedangkan suka yang berdasarkan akal masih dapat diwujudkan melalui pemenuhan material secara adil terhadap setiap istri-istri. ${ }^{35}$

\section{B.4. M. Quraish Shihab: Poligami sebagai Solusi atas Dasar Asas Kebutuhan}

Pada bahasan sebelumnya telah dijelaskan mengenai penafsiran M. Quraish Shihab tentang poligami terhadap QS. Al-Nisa'/4:3, termasuk konsep keadilan di dalamnya. Keberadaan pemikiran M. Quraish Shihab ini tidak dapat dipisahkan secara genealogis dari transformasi diskursus pemikiran-pemikiran tentang konsep poligami yang telah eksis sebelumnya. Bila ditelisik dari berbagai perbedaan yang ada, maka ditemukan setidaknya terdapat tiga kelompok besar dari klasifikasi ulama dalam diskursus konsep poligami. Tiga kelompok itu adalah mereka yang menerima secara total, kelompok yang menolak secara total, dan kelompok yang menerima dengan syarat-syarat tertentu. Berdasarkan pengelompokan itu, maka penting untuk mengetahui posisi penafsiran atau pemikiran M. Quraish Shihab di tengah perdebatan dari kelompok-kelompok tersebut. Hal ini dilakukan untuk mengetahui letak urgensi pemikiran M. Quraish Shihab dalam diskursus pemikiran tentang poligami, serta memahami pemikirannya tentang poligami untuk membumikan pesan-pesan al-Qur'an yang sesuai dengan konteks masyarakat Islam di Indonesia.

Kelompok pertama adalah kelompok yang mendukung poligami. Kelompok ini menganggap bahwa poligami merupakan bagian dari Sunnah Rasul. Pandangan itu mereka dasarkan pada QS. Al-Nisa/4:3, dengan argumen bahwa di dalamnya menggunakan fi' il amar (perintah). Selain itu, ditemukan juga fakta historis bahwa Nabi Muhammad melakukan poligami, sehingga indikasi itulah yang membuat mereka yakin bahwa poligami merupakan bagian dari syariat yang disunnahkan. ${ }^{36}$ Al-Jurjawi menyebut bahwa setidaknya ada tiga

\footnotetext{
${ }^{31}$ Shihab, Tafsir Al-Misbah, 321; M. Quraish Shihab, Al Lubab: Makna, Tujuan dan Pelajaran Dari Surahsurah al Qur'an (Tangerang: Lentera Hati, 2012), 166.

${ }^{32}$ Shihab, Wawasan Al-Qur'an, Tafsir Tematik atas Pelbagai Persoalan Umat, 156.

${ }^{33}$ Shihab, Tafsir Al-Misbah, 581.

${ }^{34}$ Shihab, Al Lubab, 222.

${ }^{35}$ Shihab, Tafsir Al-Misbah, 582.

${ }^{36}$ Muhammd, Rachman, dan Sofyan, Ijtihad Kyai Husein, 18.
} 
hikmah dari perintah syariat poligami itu, Pertama, terbatasnya poligami pada empat istri, sehingga hal itu menunjukkan bahwa tubuh terdiri dari empat campuran. Kedua, batasan empat istri sesuai dengan empat jenis mata pencaharian laki-laki, yaitu perdagangan, pertanian, pemerintahan dan industri. Ketiga, jika seorang suami memiliki empat orang istri maka seorang suami dapat mengalokasikan waktu kosong selama tiga hari yang cukup untuk mencurahkan kasih sayang kepada istri-istri mereka. ${ }^{37}$

Siti Ropiah melansir beberapa alasan kelompok pendukung poligami. Di antaranya adalah poligami dinilai mampu membantu mewujudkan keseimbangan jumlah penduduk yang saat ini lebih banyak perempuan. Hal ini dikhawatirkan jika poligami tidak dilakukan atau tidak diperbolehkan, maka akan menimbulkan banyak sekali perempuan yang tidak akan menikah atau tidak mendapat suami, sehingga para perempuan tersebut mengganggu suami orang lain atau bahkan menjual dirinya, semua ini akan merusak kestabilan dan moralitas masyarakat. Alasan lainnya dari kelompok ini adalah dengan terjadinya poligami, maka akan memperbanyak keturunan yang diyakini membanggakan Nabi Muhammad. ${ }^{38}$ Abdul Moqsith mengatakan bahwa bagi kelompok ini, kata al-Nis $\bar{a}$ ' dalam QS. Al-Nisa/4:3 merujuk kepada makna umum yang tidak dapat dispesifikasi dengan angka. Angka tersebut merupakan angka untuk menunjukkan banyaknya perempuan yang boleh dinikahi oleh laki-laki. ${ }^{39}$

Kelompok kedua adalah kelompok yang menolak poligami. Kelompok ini mengatakan bahwa perintah menikahi lebih dari satu perempuan dalam QS. al-Nisa/4:3 ini masih belum dapat dipastikan. Hal ini karena kesepakatan ulama hanya sampai mengatakan bahwa hukum asal menikah adalah mubah, bukan wajib. Dengan demikian, maka hukum asal poligami juga mubah, bukan sunnah, apalagi wajib. Kelompok ini bahkan juga memosisikan hukum poligami dapat menjadi haram, hal ini sebagaimana Nabi Muhammad pernah melarang Ali bin Abi Ṭālib untuk berpoligami. ${ }^{40}$ Jika dilihat dari perkembangannya, kelompok yang menolak tindakan poligami ini cenderung dari kelompok gender atau feminis. Abd. Moqsith mengatakan bahwa kelompok ini banyak didominasi oleh kelompok yang menyuarakan kesetaraan dan keadilan gender. ${ }^{41}$

Fazlur Rahman menyatakan bahwa pesan utama dari al-Qur'an dalam QS. Al-Nisa'/4:3 pada dasarnya adalah perintah untuk monogami bukan poligami. ${ }^{42}$ Hal yang senada juga diungkapkan oleh Haifah A. Jawad, sebagaimana dikutip Anis Nur Arifah yang memandang bahwa poligami yang dilakukan hanya karena nafsu birahi seksual yang tidak dilandasi alasan yang jelas dan kuat, maka harus dicegah. ${ }^{43}$ Masjuk Zuhdi juga menilai bahwa poligami dapat menjadi sumber konflik dalam kehidupan keluarga, baik konflik antara suami dengan istri-istri dan anak-anak dari istri-istrinya, maupun konflik antara istri beserta anak-anaknya masingmasing. Oleh sebab itu, hukum asal perkawinan dalam Islam adalah monogami, sebab dengan monogami akan mudah menetralisir sifat atau watak cemburu, iri hati dan suka mengeluh dalam keluarga monogamis. Berbeda dengan kehidupan keluarga yang poligamis, orang akan mudah peka dan terangsang timbulnya perasaan cemburu, iri hati, dengki dan suka mengeluh dalam

\footnotetext{
${ }^{37}$ Ali Ahmad al-Jarjawi, Hikmah al-Tasyri'wa Falsafatuhu (Bairut: Dar al-Fikr, t.t.), 10.

${ }^{38}$ Siti Ropiah, "Studi kritis poligami dalam islam (analisa terhadap alasan pro dan kontra poligami)," AlAfkar, Journal for Islamic Studies 1, no. 1 (2018): 90-91.

${ }^{39}$ Abd Moqsith, "Tafsir atas Poligami dalam al-Qur'an," KARSA: Journal of Social and Islamic Culture 23, no. 1 (2015): 136, https://doi.org/10.19105/karsa.v23i1.613.

${ }^{40}$ Ropiah, "Studi kritis poligami dalam islam (analisa terhadap alasan pro dan kontra poligami)," 90-91.

${ }^{41}$ Moqsith, "Tafsir atas Poligami dalam al-Qur'an,” 141.

${ }^{42}$ Taufik Adnan Amal, Islam dan Tantangan Modernitas: Studi Atas Pemikiran Hukum fazlur Rahman (Bandung: Mizan, 1996), 190.

${ }^{43}$ Anis Nur Arifah, "Poligami Kiai: Praktek Poligami Kiai di Kota Jember dalam Pandangan KHI dan Gender," YUDISIA: Jurnal Pemikiran Hukum dan Hukum Islam 7, no. 1 (2016): 141, http://dx.doi.org/10.21043/yudisia.v7i1.2134.
} 
kadar tinggi, sehingga bisa mengganggu ketenangan keluarga dan dapat membahayakan keutuhan keluarga. ${ }^{44}$ Itulah sebabnya, Raden Ajeng Kartini juga dikenal di Indonesia sebagai sosok wanita yang gigih memperjuangkan penolakannya terhadap tradisi poligami, ${ }^{45}$ bahkan hingga saat ini, gerakannya itu telah dikembangkan secara pesat di Indonesia oleh para penggiat feminisme. ${ }^{46}$

Kelompok ketiga adalah kelompok yang membolehkan poligami dengan syarat dan keadaan tertentu. Kelompok ini umumnya menekankan pada aspek keadilan dan ketentuan lainnya ketika seseorang hendak melakukan praktik poligami. Kelompok ini didominasi oleh para pemikir kontemporer di antaranya, Sayyid Qutb yang menilai bahwa praktik poligami hanya sebagai sebuah rukhṣah, sehingga kebolehannya hanya sebatas jika seorang laki-laki berada dalam keadaan darurat, serta dengan syarat mampu berbuat adil kepada istri-istrinya. Bentuk keadilan yang diinginkan dalam hal ini termasuk dalam aspek nafkah, mu'amalah dan pembagian malam hari. Jika seorang laki-laki tidak mampu berbuat adil, maka hanya boleh beristri satu orang perempuan saja, namun jika hal itu mampu dipenuhinya, maka diperbolehkan berpoligami dengan batasan maksimal empat orang istri. ${ }^{47}$ Demikian halnya Muhammad Syahrur yang memutlakkan dua syarat yang harus dipenuhi oleh seorang laki-laki yang hendak berpoligami yaitu, Pertama, istri kedua, ketiga dan keempat telah berstatus janda, serta telah memiliki anak yatim. Kedua, khawatir bila tidak berpoligami, maka dia tidak mampu bersikap adil kepada anak-anak yatim. Jika syarat-syarat ini tidak dipenuhi, maka kebolehan poligami menjadi gugur. ${ }^{48}$ Nova Helida menyebutkan bahwa keadilan dalam poligami ini tidak sekedar aspek kuantitatif seperti pemberian nafkah berupa makan, minum, pakaian dan tempat tinggal. ${ }^{49}$ Pendapat ini senada dengan apa yang diungkapkan oleh al-Dahhak serta ulama lainnya yang menegaskan bahwa adil dalam poligami adalah adil dalam banyak aspek, materi maupun immateril. Suami diharuskan berbuat adil dalam hal cinta, kasih sayang, nafkah, giliran menginap, tempat tinggal dan lain sebagainya. ${ }^{50}$

Keadilan yang diisyaratkan oleh al-Qur'an menurut Muhammad Abduh adalah bersifat kualitatif yang tidak bisa diukur secara statistik, yaitu cinta, kasih sayang dan perhatian. Muhammad Abduh melanjutkan apabila hak-hak istri tidak mampu dipenuhi oleh suaminya, maka akan terjadi kerusakan dan kekacauan dalam keluarganya. Demikian ini karena pilar utama kehidupan keluarga adalah kesatuan dan rasa sayang yang menyelimuti antar anggota keluarga. ${ }^{51}$ Keadilan kualitatif yang disebut oleh Muhammad Abduh di atas senada dengan mayoritas ahli fikih yang menilai bahwa mustahil seorang suami bisa mewujudkannya. Abdurrahman al-Jazīīī menyebut bahwa sangat naluriah seseorang tidak mampu berbuat adil

\footnotetext{
${ }^{44}$ Masjuk Zuhdi, Masail Fiqhiyyah (Jakarta: CV. Haji Masagung, 1989), 12.

${ }^{45}$ Muhajir Muhajir, "Perempuan dan Poligami dalam Tiga Cerita Pendek (Patriarchy and Polygamy in Three Indonesia Short Stories)," Alayasastra 14, no. 2 (2018), https://doi.org/10.36567/aly.v14i2.202.

${ }^{46}$ Lihat lebih jauh beberapa pandangan tentang penolakan praktik poligami dalam Siti Musdah Mulia, Islam Menggugat Poligami (Jakarta: Gramedia Pustaka Utama, 2007); Mahmud Muhammad Taha, Arus Balik Syari'ah, Yogyakarta (LKiS: 2003, t.t.); Asghar Ali Engineer, Hak-hak Perempuan dalam Islam, trans. oleh Farid Wajidi (Yogyakarta: LSPPA \& CUSO, 1994); Khoiruddin Nasution, Riba dan Poligami: Sebuah Studi atas Pemikiran Muhammad Abduh (Yogyakarta: Pustaka Pelajar, 1996).

${ }^{47}$ Sayyid Qutb, Tafsir fi Dzilalil Qur'an (Jakarta: Gema Insani Press, 2001), 275.

${ }^{48}$ Muhammad Syahrur, Naḥwa Ușūl Jadīdah li al-Fiqh al-Islāmī: Fiqh Al-Mar'ah (Damsiq: Al-Ahali, 2000), 303.

${ }^{49}$ Nova Helida, "Akibat hukum pembatalan perkawinan poligami yang disebabkan ketiadaan izin isteri pertama ditinjau dari undang-undang Nomor 1 Tahun 1974 tentang perkawinan: Analisis putusan pengadilan Agama nomr 822/Pdt. G/2004/PA.” (Tesis, Depok, Universitas Indonesia, 2011), 36.

${ }^{50}$ Syihab al-Din Abi al-Abbas Ahmad bin Muhammad al-Syafi'i al-Qastalani, Irsyād al-Sārī Syarh Șaḥịh al-Bukhārī, vol. XI (Beirut: Dar al-Kutub al-Ilmiyyah, 1996), 502.

${ }^{51}$ Muhammad Abduh dan Muhammad Rasyid Ridha, Tafsir Al-Qur'ān Al-Hakìm (Beirut: Dar Al-Kutub Al-'Ilmiyah, 1999), 284-85.
} 
dalam berbagi kasih sayang dan perhatian. Sehingga sangat wajar jika seorang suami lebih perhatian pada salah satu istrinya melebihi yang lainnya, karena hal tersebut di luar kemampuan manusia. ${ }^{52}$

Pemikiran M. Quraish Shihab tampaknya lebih cenderung sejalan dengan kelompok ketiga, yakni ulama yang membolehkan praktik poligami dengan syarat dan keadaan yang sangat ketat. Sebagaimana telah dijelaskan bahwa M. Quraish Shihab menjadikan praktik poligami layaknya pintu darurat, yang hanya dapat dilewati ketika dalam keadaan darurat dan tidak ada lagi jalan lain. Klaim itu di dasarkan pada berbagai pernyataan M. Quraish Shihab yang tidak menolak serta tidak juga menerima sepenuhnya praktik poligami. Akan tetapi, walaupun pemikiran M. Quraish Shihab senada dengan beberapa pemikiran dari kelompok ketiga, seperti Sayyid Quțub, Muhammad Syahrur, Muhammad Abduh dan lainnya, namun artikulasi term adil yang ditetapkannya termasuk unik karena bertumpu pada keadilan dalam aspek material semata.

\section{Penutup}

M. Quraish Shihab dalam menyikapi konsep poligami yang tertuang dalam QS. AlNisa/4:3 ternyata tidak hanya terfokus pada makna teks dari redaksi ayat sebagaimana yang dilakukan oleh para penggiat poligami, melainkan dia juga melibatkan konteks turunnya ayat dan konteks sejarah turunnya ayat tersebut. Melalui proses penafsiran itulah, M. Quraish Shihab menyimpulkan bahwa QS. Al-Nisa/4:3 tidak berorientasi pada perintah yang mewajibkan praktik poligami. Menurutnya, ayat itu justru menjadi penegasan terhadap kehatian-kehatian seorang laki-laki yang hendak melakukan poligami, serta persoalan rumah tangga yang dihadapinya hanya dapat diselesaikan dengan cara poligami. Itulah sebabnya, bagi M. Quraish Shihab poligami bukanlah karena asas keinginan melainkan asas kebutuhan. Dengan demikian, seorang laki-laki yang hendak melakukan poligami agar mempertimbangkan secara matang, khususnya kemampuannya untuk bersikap adil dalam aspek material. Pemikiran M. Quraish Shihab tersebut merupakan bagian dari pemikiran kelompok yang menerima praktik poligami dengan syarat-syarat yang ketat. Pandangan M. Quraish Shihab termasuk tergolong moderat dalam menyelesaikan problem praktik poligami di Indonesia, di mana M. Quraish Shihab berusaha bersikap moderat atas pandangan para penggiat dan penolak praktik poligami. Namun demikian, penelitian ini masih terbatas pada pemikiran berdasarkan penafsiran M. Quraish Shihab terhadap QS. al-Nisa/4:3 terkait artikulasi adil dalam berpoligami, sehingga masih terbuka peluang untuk meneliti lebih lanjut keterpenuhan aspek adil dalam berbagai praktik poligami dalam konteks ke-Indonesiaan.

\section{DAFTAR PUSTAKA}

Abduh, Muhammad, dan Muhammad Rasyid Ridha. Tafsir Al-Qur'an Al-Hakim. Beirut: Dar Al-Kutub Al-'Ilmiyah, 1999.

Ali, Syed Ameer. The Spirit of Islam. Diterjemahkan oleh HB. Jasin. Jakarta: Bulan Bintang, 2000.

Amal, Taufik Adnan. Islam dan Tantangan Modernitas: Studi Atas Pemikiran Hukum fazlur Rahman. Bandung: Mizan, 1996.

Al-Aqqad, Abbas Mahmud. al-Mar'ah fi Al-Qur'an. Diterjemahkan oleh Chadijah Nasution. Jakarta: Bulan Bintang, 1987.

Arifah, Anis Nur. "Poligami Kiai: Praktik Poligami Kiai di Kota Jember dalam Pandangan KHI dan Gender." YUDISIA: Jurnal Pemikiran Hukum dan Hukum Islam 7, no. 1 (2016): 120-145. http://dx.doi.org/10.21043/yudisia.v7i1.2134.

Asiyah, Siti, Muhammad Irsad, Eka Prasetiawati, dan Ikhwanudin Ikhwanudin. "Konsep Poligami dalam Alquran: Studi Tafsir Al-Misbah Karya M. Quraish Shihab.” Fikri:

${ }^{52}$ Abdurrahman al-Jaziri, Kitab al Fiqh 'ala al-Mażāhib al-'Arba'ah (Mesir: al-Maktabah al-Tijariyyah, 1969), 239. 
Jurnal Kajian Agama, Sosial dan Budaya 4, no. 1 (2019): 85-100. https://doi.org/10.25217/jf.v4i1.443.

Bahron, Ali. "Pemikiran M. Quraish Shihab tentang Adil dalam Poligami." Skripsi, IAIN Jember, 2015.

Dewan Redaksi. Suplemen Ensiklopedi Islam. Jakarta: Ichtiar Baru Van Hoeve, 1994.

Dhafir, Achmad. "Asas-asas Berpoligami dalam al Qur'an: studi dalam Tafsir al Misbah karya M. Quraish Shihab.” Tesis, UIN Sunan Ampel, 2018.

Engineer, Asghar Ali. Hak-hak Perempuan dalam Islam. Diterjemahkan oleh Farid Wajidi. Yogyakarta: LSPPA \& CUSO, 1994.

Federspiel, Howard M., Tajul Arifin, dan Rachmat Taufiq Hidayat. Kajian Al-Quran Di Indonesia: Dari Mahmud Yunus Hingga Quraish Shihab. Bandung: Mizan, 1996.

Gusmian, Islah. Khazanah Tafsir Indonesia DAri Hermeneutika hingga Ideologi. Yogyakarta: LKiS, 2013.

Helida, Nova. "Akibat hukum pembatalan perkawinan poligami yang disebabkan ketiadaan izin istri pertama ditinjau dari undang-undang Nomor 1 Tahun 1974 tentang perkawinan: Analisis putusan pengadilan Agama nomr 822/Pdt. G/2004/PA.” Tesis, Universitas Indonesia, 2011.

Hijrah, Hijrah. "Pemikiran Quraish Shihab tentang Poligami dan Relevansinya terhadap Kompilasi Hukum Islam dan UU No. 1 Tahun 1974 Tentang Perkawinan di Indonesia: Studi atas Karya-karya Quraish Shihab.” Tesis, Universitas Islam Negeri Mataram, 2017.

Jarjawi, Ali Ahmad al-. Hikmah al-Tasyrī’ wa Falsafatuhu. Bairut: Dar al-Fikr, t.t.

Jaziri, Abdurrahman al-. Kitab al Fiqh 'ala al-Mażāhib al-'Arba'ah. Mesir: al-Maktabah alTijariyyah, 1969.

Kementrian Agama RI. al-Jamil: Al-Qur'an Tajwid Warna, Terjemah per Kata, Terjemah Inggris. Bekasi: Cipta Bagus Segera, 2012.

Khotim, Ahmad, dan Gempur Malessantoro. "Adil Dalam Poligami Menurut Kyai Di Jombang Perspektif M. Quraish Shihab.” At-Tahdzib: Jurnal Studi Islam dan Muamalah 7, no. 2 (2019): 80-99.

Lajnah Pentashihan Mushaf Al-Qur'an Badan Litbang dan Diklat Kementerian Agama RI, AlQur'an Dan Terjemahnya; Edisi Penyempurnaan (Jakarta, 2019)

Moqsith, Abd. "Tafsir atas Poligami dalam al-Qur'an." KARSA: Journal of Social and Islamic Culture 23, no. 1 (2015): 132-148. https://doi.org/10.19105/karsa.v23i1.613.

Muhajir, Muhajir. "Perempuan dan Poligami dalam Tiga Cerita Pendek (Patriarchy and Polygamy in Three Indonesia Short Stories)." Alayasastra 14, no. 2 (2018). https://doi.org/10.36567/aly.v14i2.202.

Muhammd, Husein, Noor Rachman, dan A. Dicky Sofyan. Ijtihad Kyai Husein: upaya membangung keadilan gender. Jakarta: Rahima, 2011.

Mulia, Siti Musdah. Islam Menggugat Poligami. Jakarta: Gramedia Pustaka Utama, 2007.

Muttakin, Moch Cholik Chamid. 'Konsep Poligami Perspektif Al-Qur'an (Studi Komparasi Pemikiran Ar-Razi \& M Quraish Shihab).” Skripsi, IAIN Tulungagung, 2018.

Nasution, Khoiruddin. Riba dan Poligami: Sebuah Studi atas Pemikiran Muhammad Abduh. Yogyakarta: Pustaka Pelajar, 1996.

Nasution, Rusli Halil. "Adil Menurut Quraish Shihab dalam Al-Qur'an terhadap Praktik Poligami." Jurnal Hukum Responsif 6, no. 6 (2019): 21-31.

Qastalani, Syihab al-Din Abi al-Abbas Ahmad bin Muhammad al-Syafi'i al-. Irsyād al-Sārī Syarh Șahīh al-Bukhārī. Vol. XI. Beirut: Dar al-Kutub al-Ilmiyyah, 1996.

Qutb, Sayyid. Tafsir fi Dzilalil Qur'an. Jakarta: Gema Insani Press, 2001.

Ropiah, Siti. "Studi Kritis Poligami dalam Islam (Analisa terhadap Alasan Pro dan Kontra Poligami)." Al-Afkar, Journal for Islamic Studies 1, no. 1 (2018): 89-104.

Sabiq, Sayyid. Fikih Sunnah. Diterjemahkan oleh al-Ma'arif. Bandung, 1987.

Shihab, M. Quraish. Al Lubab: Makna, Tujuan dan Pelajaran Dari Surah-surah al Qur'an. Tangerang: Lentera Hati, 2012.

. Menabur Pesan Ilahi; Al-Qur'an dan Dinamika Kehidupan Masyarakat. Jakarta: Lentera Hati, 2006.

. Mukjizat al-Qur'an Ditinjau dari Aspek Kebahasaan, Isyarat Ilmiah, dan Pemberitaan Gaib. Bandung: Mizan, 2002. 
- Perempuan. Tangerang: Lentera Hati, 2014.

Secercah Cahaya Ilahi: Hidup Bersama al-Quran. Bandung: Mizan, 2013.

-.Wawasan Al-Qur'an, Tafsir Tematik atas Pelbagai Persoalan Umat. Bandung: Mizan, 1996.

Shihab, Quraish. Tafsir Al-Misbah Pesan, Kesan dan Keserasian al-Qur'an. Jakarta: Lentera Hati, 2011.

Syahrur, Muhammad. Naḥwa Ușūl Jadīdah li al-Fiqh al-Islāmī: Fiqh Al-Mar'ah. Damsiq: AlAhali, 2000.

Taha, Mahmud Muhammad. Arus Balik Syari'ah,. Yogyakarta. LKiS: 2003, t.t.

Tatapangarsa, Humaidi. Hakekat poligami dalam Islam. Jakarta: Usaha Nasional, 1999.

Yasmanto, Ali. "Konsep Adil dalam Poligami: Studi Komparasi antara Pemikiran Fazlur Rahman dan M. Quraish Shihab." Tesis, Universitas Islam Negeri Maulana Malik Ibrahim, 2015.

Zuhdi, Masjuk. Masail Fiqhiyyah. Jakarta: CV. Haji Masagung, 1989. 